\title{
EDITORIAL
}

\section{Germany Proposes Documentation Rules}

\author{
Toshiaki Katsushima, Deloitte \& Touche Tohmatsu, Japan
}

Although the document is only in draft form at the time of writing, it appears that the German tax authorities have joined the ranks of countries that have imposed onerous documentation requirements on companies operating within their borders. The German rules purport to govern all aspects of transfer pricing audits (not just documentation) and include a number of provisions that are sure to cause some concern among multinational corporations that are subject to German audits. I will discuss two of the more controversial provisions below.

In the course of a transfer pricing audit German auditors often request documents that are part of the books and records of a foreign affiliate. In the past, taxpayers sometimes claimed that they could not obtain such records because the foreign affiliate was unwilling to provide them. Under the draft ruling this claim will no longer be available because the German taxpayer is required to agree with the foreign affiliate at the time of the transaction that the affiliate will provide all necessary information upon request. It will not be a defense to a request for foreign documents that the time period for retaining such documents in the foreign country has expired; the German taxpayer is still required to secure the documents. The German taxpayer that does not arrange to obtain the necessary information from the foreign affiliate, and therefor does not fully comply with its duty to cooperate with the tax authorities, could be subject to an adjustment to its transfer prices based on an estimate. This estimate can be based on a general set of industry data and does not need to be exact. This result is similar to the result that can occur in the United States, where there is a similar duty to produce documents that are within the control of a foreign entity, and a similar result if the documents are not produced. In light of the practical difficulties that exist with regard to obtain- ing information from, for example, a foreign parent that is not controlled by the German taxpayer, or from an entity that no longer maintains the information, it remains to be seen how this provision will be enforced by the German tax authorities. Certainly no guidance is provided by the draft of the new rules.

Regarding the documentation rules themselves, there are some provisions that are bound to create controversy. First, there are a number of documents, including the materials a taxpayer has prepared for tax authorities of other countries, that must be provided at the beginning of a transfer pricing audit, without a specific request from the auditor. It has been the practice of some German auditors in recent years to request a copy of a taxpayer's US documentation. The draft new rules make that position official and expand the scope of information to all documents that have been prepared for the tax authorities in all other countries. In light of this requirement it becomes even more important for German taxpayers to take a unified, consistent approach to their overall, worldwide documentation. Even if the methodology used to arrive at the transfer prices differs from country to country, it will be important for the taxpayer to reconcile the different methodologies when preparing its transfer pricing report.

The draft rules also include a specific requirement that the companies involved in electronic commerce provide a list of web sites, locations of servers, information about bandwidth, data traffic and network utilisation, and other items associated with services provided over the internet. This may signal that the German tax authorities, unlike those in other countries, might be considering imposing taxes on internet-based activities. At the very least, it signals a heightened scrutiny of e-commerce that bears watching by companies engaging in such activity in connection with Germany. 